\title{
The Effect of Giving Dadih on Malondialdehyde Levels and Renal Interstitial Fibrosis at Aging Kidney
}

\author{
Harnavi Harun ${ }^{1 \star}$, Yanwirasti Yanwirasti ${ }^{2}$, Bambang Purwanto ${ }^{3}$, Endang Purwati Rahayuningsih ${ }^{4}$ \\ ${ }^{1}$ Department of Internal Medicine, Faculty of Medicine, Andalas University/Dr. M. Djamil Central General Hospital, Padang, \\ Indonesia; ${ }^{2}$ Department of Anatomy, Faculty of Medicine, Andalas University, Padang, West Sumatera, Indonesia; ${ }^{3}$ Department \\ of Internal Medicine, Faculty of Medicine, Sebelas Maret University, Solo, Indonesia; ${ }^{4}$ Department of Biotechnology, Faculty of \\ Animal Husbandry, Andalas University, Padang, Indonesia
}

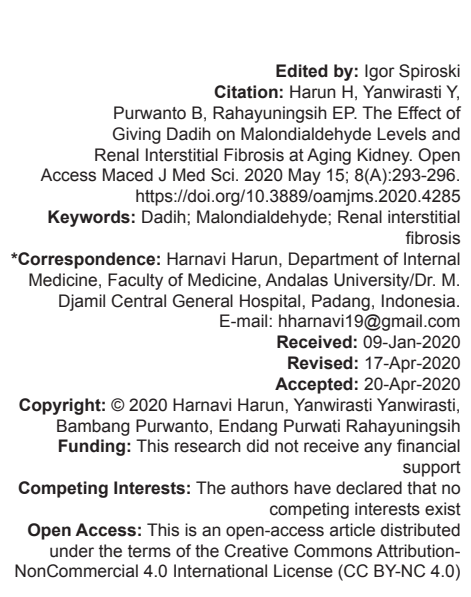

\section{Introduction}

Life expectancy nowadays is increasing both globally and nationally. Increasing old age is encouraging because of an increase in welfare, but on the other hand it creates problems. This is due to the aging process leading to decreased physiological function of the body's organs progressively. As a result, there will be adaptive disturbances and homeostatic mechanisms that lead to vulnerability to environmental or internal stresses with an increase in various diseases [1].

One of the well-known aging theory states that the normal aging process is caused by free radicals that are formed endogenously as a by-product of metabolic processes that use oxygen. Mitochondria play an important role in the aging process because these organelles are the main source of free radicals production, as a side effect of energy formation. In young mitochondria, this condition can overcome by the presence of antioxidants found in the body. However, in old mitochondria, it is not enough to produce antioxidants needed to neutralize free radicals that are formed so that there is an imbalance between the productions of free radicals with antioxidants [2]

As a result of this imbalance, between the formations of free radicals (reactive oxygen compounds) with the required antioxidants, there will be damage to body tissue called oxidative damage. Reactive oxygen species (ROS) can attack all types of biomolecules, especially unsaturated fatty acids which are important components of the phospholipids making up cell membranes [2], [3].

When free radicals, especially hydroxide radicals react with these unsaturated fatty acids, there will be a chain reaction known as lipid 
peroxidation. Decomposition of lipid peroxidation will produce hydroperoxides which will affect membrane function. One of the products of this hydroperoxide is malondialdehyde (MDA) which is a marker of oxidative damage that can be inhibited by giving antioxidants from outside the body [4].

MDA is a lipid peroxidation product. When lipids react with free radicals, there will be a process of peroxidation to form lipid peroxide. These lipid peroxides will induce endothelial damage and inflammatory responses, inhibit vasodilation and activate macrophages [5], [6]. Activated macrophages will express cytokines, including transforming growth factor-beta 1 (TGF- $\beta 1$ ), tumor necrosis factor-alpha 1 , interleukin (IL) -1 beta, IL-6, and IL-8. TGF- $\beta 1$ is the dominant cytokine involved in the pathogenesis of interstitial fibrosis and glomerulosclerosis in the aging kidney which can then develop into chronic kidney disease (CKD) marked by albuminuria [7].

Kidney fibrosis is known as a common pathological feature of aging kidney leading to CKD even end-stage renal disease. This condition is characterized by excessive deposition of extracellular matrix (ECM). A number of studies show that TGF- $\beta 1$ is a key mediator in CKD associated with progressive renal fibrosis [7]. In general, in aging, endogenous antioxidants are not enough to prevent oxidative damage. Therefore, we need another source of antioxidants that can stimulate endogenous antioxidants. Some researchers found that fermented milk contains peptides which act as antioxidants [8].

Fermented milk peptides have functional properties as antioxidants, antithrombotics, antihypertensives, hypocholesterolemia, antimicrobials, and as immunomodulators [9]. Milk and milk derivate products such as fermented milk contain biologically active peptides. Bioactive peptides are food components that have biological functions on health both to cure and prevent disease [9].

One of the fermented milk which is known as the traditional food of the people of West Sumatra is dadih. Dadih (called "dadiah" in West Sumatera) is a processed product from buffalo milk made by natural fermentation by lactic acid-producing bacteria in bamboo at room temperature for 2-3 days and has a distinctive sour taste. Dadih contains nutritious nutrients and probiotics [10].

Recent research has given new hope that probiotics have antioxidant abilities. In vivo and in vitro probiotics are proven to increase the body's antioxidants. Probiotics can increase SOD and GPX activity and reduce MDA in rabbit serum [11], [12], [13].

Based on the above background, the researchers wanted to prove the effect of giving dadih on MDA and interstitial fibrosis of kidney tissue on the aging kidney.

\section{Materials and Methods}

This was an experimental study with posttest only control group design conducted to observe effect of dadih to kidney aging of Rattus norvegicus in the Pharmacy Laboratory at Andalas University, Biomedical and Anatomical Pathology Laboratory at Medical Faculty of Andalas University. This study was conducted from January until June 2019.

\section{Samples}

Thirty male white rats ( $R$. norvegicus) aged 24 months and weighing $450 \mathrm{~g}$ were divided into three groups. Each group consisted of 10 animals divided into Group K (control group that was only given aquadest as a dadih solvent), Group P1 (the treatment group was given dadih as much $4.5 \mathrm{~g}$ once a day dissolved in aquadest), and Group P2 (group the treatment is given dadih as much as $4.5 \mathrm{~g}$ twice a day which is dissolved in aquadest). Giving dadih is given for 42 days. Dadih used came from Air Dingin, Alahan Panjang, Solok, West Sumatra.

\section{Examination of MDA levels}

MDA level examination conducted by the thiobarbituric acid reactive substances method in Biomedical Laboratory of the Faculty of Medicine, Andalas University, Padang.

\section{Examination of histopathology tissue}

Kidney tissue is used for interstitial fibrosis examination by histopathology examination with Sirius Red staining in Anatomical Pathology Laboratory at Medical Faculty of Andalas University, Padang.

\section{Data analysis}

The results obtained MDA levels $(\mathrm{pg} / \mathrm{ml})$ and kidney interstitial fibrosis in the initial stages were tested for normality with Shapiro-Wilk. If it is not normally distributed, transformation is performed and then the normality test is performed. If still not normally distributed, the analysis will be non-parametric, and if normal the parametric test is carried out. If the value of $p<0.05$ means, there is significant.

\section{Research ethics}

Ethics clearance was approved by the Ethics Committee of Medical Faculty of Andalas University (No: 152/KEP/FK/2019). 


\section{Results}

Before analyzing the effect of dadih on MDA levels and kidney interstitial fibrosis, a normality test was performed. The normality test results found that MDA levels and kidney interstitial fibrosis were not normally distributed so transformation was performed with Log10. After the transformation of the data and normality test, it turns out that the MDA has been normally distributed $(p>0.05)$ while the data of kidney interstitial fibrosis is not normally distributed so that the test is a non-parametric Kruskal-Wallis test. The effect of dadih on MDA levels in kidney tissue can be seen in Tables 1 and 2.

Table 1: Effects of giving dadih on MDA levels in kidney tissue based on MDA and TBA $(\mathrm{pg} / \mathrm{mL})$ reactions

\begin{tabular}{lllll}
\hline MDA & $\mathrm{n}$ & Average & SD & p-value \\
\hline $\mathrm{K}$ & 10 & 0.97 & 0.06 & 0.001 \\
$\mathrm{P}_{1}$ & 10 & 0.75 & 0.03 & \\
$\mathrm{P}_{2}$ & 10 & 0.75 & 0.03 & \\
\hline
\end{tabular}

Based on Table 1, there was a tendency to decrease MDA levels in the treatment group (Group P1 and Group P2) when compared to the control group (Group K), from $0.97 \pm 0.06$ to $0.75 \pm 0.03$. Statistically, this decrease was significant $(p<0.05)$. Then, the post hoc Bonferroni test was performed to determine the effect of giving a gift in each group can be seen in Table 2. It turns out that with the Group P1 alone, there has been a significant decrease in MDA levels $(p<0.05)$. However, there is no difference between Group P1 and Group P2.

Table 2: Post hoc tests treated with MDA levels of kidney tissue in each group

\begin{tabular}{lllll}
\hline Dependent variable & $(\mathrm{I})$ Group & $(\mathrm{J})$ Group & Average difference $(\mathrm{I}-\mathrm{J})$ & $\mathrm{p}$-value \\
\hline MDA & K (Control) & P1 & $0.22070^{*}$ & 0.001 \\
& & P2 & $0.22070^{*}$ & 0.001 \\
& P1 & K & $-0.22070^{*}$ & 0.001 \\
& & P2 & 0.00000 & 10.001 \\
& P2 & K & $-0.22070^{*}$ & 0.001 \\
& & P1 & 0.00000 & 10.001 \\
\hline
\end{tabular}

From the results of this study, it can be seen that giving dadih can reduce levels of MDA, which statistically, this reduction is very significant both in Group P1 and in Group P2 ( $p=0.001)$. This shows that dadih can inhibit the formation of MDA due to oxidative damage caused by an increase in free radicals caused by aging.

Fibrosis data after giving dadih are not normally distributed, so the test is a non-parametric KruskalWallis test (Table 3). The results obtained in table 3 that significant decrease in the average rank of fibrosis from group $\mathrm{K}(24.5 \%)$ then group P1 $(16.30 \%)$ and group P2 $(5.7 \%)$. Figure 1 shows the histopathology of renal fibrosis interstitial in each group. Staining of sirius red in the kidney of experimental control animals (group $\mathrm{K}$ ), single dose treatment (group P1) and double dose treatment (group P2). Collagen deposition is measured by an imageJ program by extracting red colored areas, converting images to grayscale and measuring the
Table 3: Effects of giving Dadih on kidney interstitial fibrosis (Kruskal-Wallis) (\%)

\begin{tabular}{llll}
\hline Interstitial fibrosis & $\mathrm{n}$ & Average rank & p-value \\
\hline K (control) & 10 & 24.50 & \\
P1 & 10 & 16.30 & 0.001 \\
P2 & 10 & 5.70 & \\
\hline
\end{tabular}

percentage of the total area colored per area. Collagen deposition is lower in experimental animals by giving dadih than controls. The lowest collagen deposition is group P2 with double dose dadih.

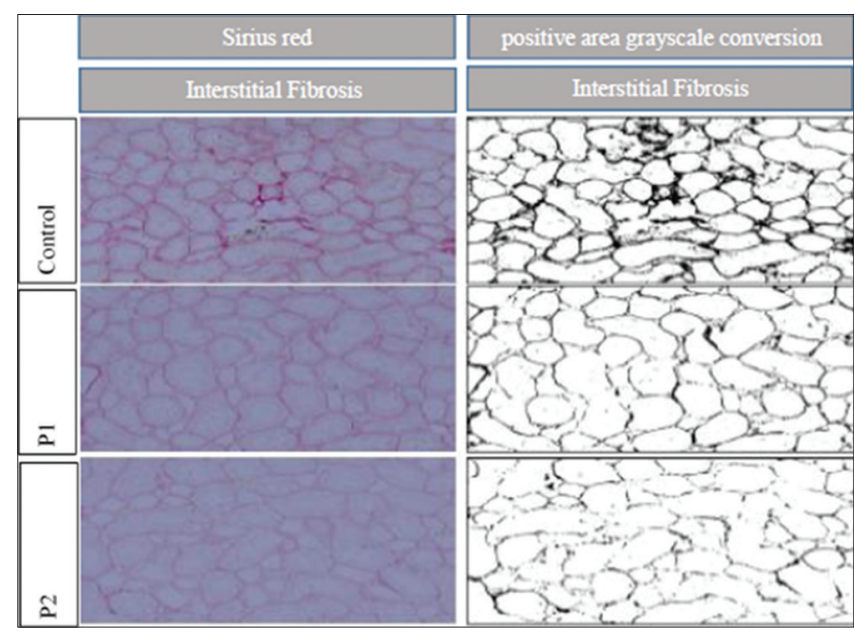

Figure 1. Histopatology of renal fibrosis interstitial in control group, group $P 1$ and group P2

\section{Discussion}

From the results of the study, it can be seen that in the treatment Group 1 and treatment Group 2, there was no difference in MDA reduction. This means that giving $4.5 \mathrm{~g}$ of dadih once a day is effective enough to inhibit the formation of MDA. Probiotics showed the effect of scavenger activity as an antioxidant by decreasing free radicals formed as oxidative processes [14]. It is suspected that dadih prevents lipid peroxidation through the above process because the dadih components that are functioned as antioxidants are peptides and lactic acid bacteria (LAB), where this $L A B$ can prevent the formation of ROS [14].

Dadih contains probiotics which are commensal microorganisms [10]. Research on probiotics as antioxidants at this time is very often done and it has been proven that probiotics can modulate antioxidants by correlating metal ions, producing antioxidants themselves, regulating the antioxidant activity of hosts, and reducing the activity of enzymes that produce ROS [11], [13]. This shows that dadih can inhibit the formation of MDA due to oxidative damage caused by an increase in free radicals due to aging.

Kidney fibrosis is known as common pathological features of the aging kidney. This condition is characterized by excessive deposition of the ECM. 
Collagen is a major component of ECM in the kidneys and is associated with gradations of disease [7]. The results of this study statistically sign show that giving dadih in the treatment Group 1 and in the treatment Group 2 can reduce fibrosis rate when compared to the Control group. Since the data obtained are not normally distributed, the significant test cannot be carried out. The analysis is only done based on the average rank of fibrosis. Results of staining with Sirius red staining, fibrocolagen matrix deposition is lower in the test animals given dadih.

Research experts show that TGF- $\beta 1$ plays a key role in kidney fibrosis. TGF- $\beta 1$ also regulates ECM synthesis and increases fibrogenic bFGF ${ }_{2}$. TGF$\beta 1$ expression acts as a chemoattractant for fibroblasts in the early phase of fibrosis. TGF- $\beta 1$ also induces the transformation of tubular epithelial cells into myofibroblasts and smooth muscle cells through the induction of ECM protein [7]. The results of the study can explained that dadih can reduce renal interstitial fibrosis.

\section{Conclusion}

From the results of this study, it can be concluded that dadih is a natural exogenous antioxidant, which can reduce oxidative damage in aging kidney by reducing MDA levels in kidney tissue so that it can inhibit renal interstitial fibrosis. Thus, this study can contribute clinically to improve the prognosis and as additional therapy in protection and inhibition of progression of CKD.

\section{References}

1. Campbell $\mathrm{KH}, \mathrm{O}$ 'Hare AM. disease in the elderly: Update on recent literature. Curr Opin Nephrol Hypertens. 2008;17(3):298-303. PMid:18408482

2. Goldsmith TC. Modern evolutionary mechanics theories and resolving the programmed/non-programmed aging controversy. Biochemistry (Mosc). 2014;79(10):1049-55. https://doi. org/10.1134/s000629791410006x PMid:25519063

3. Stuart JA, Maddalena LA, Merilovich M, Robb EL. A midlife crisis for the mitochondrial free radical theory of aging. Longev Healthspan. 2014;3:1-15. https://doi. org/10.1186/2046-2395-3-4

PMid:24690218

4. Small DM, Coombes JS, Johnson B, Gobe GC. Oxidative stress, anti-oxidant therapies and chronic kidney disease. Nephrology. 2012;17(4):311-21. https://doi. org/10.1111/j.1440-1797.2012.01572.x

PMid:22288610

5. Li G, Chen Y, Hu H, Liu L, Hu X. Association between agerelated decline of kidney function and plasma malondialdehyde. Rejuvenation Res. 2012;15(3):257-67. https://doi.org/10.1089/ rej.2011.1259

PMid:22530729

6. Frijhoff J, Winyard PG, Zarkovic N, Davies SS, Stocker R, Cheng $\mathrm{D}$, et al. Clinical relevance of biomarkers of oxidative stress. Antioxid Redox Signal. 2015;23(14):1144-70. https://doi. org/10.1089/ars.2015.6317

PMid:26415143

7. Lan $\mathrm{H}$ Y. Diverse roles of TGF- $-\beta /$ smads in renal fibrosis and inflammation. Int J Biol Sci. 2011;7(7):1056-67. https://doi. org/10.7150/ijbs.7.1056

\section{PMid:21927575}

8. Clare, DA, Swaigood, HE. Bioactive milk peptides: A prospectus J Dairy Sci. 2000;83(6):1187-95.

PMid:10877382

9. Korhonen $\mathrm{H}$, Pihlanto A. Bioactive peptides: Production and functionality. Int Dairy J. 2006;16:945-60. https://doi. org/10.1016/j.idairyj.2005.10.012

10. Rusfidra PE, Juliyarsi AI, Purwanto H. Plasma Nutfah Sumatera Barat Dadiah Sebagai Pangan Fungsional Probiotik Menunjang Kesehatan Masyarakat. Bogor: Cendikia; 2010. https://doi. org/10.25077/car.9.9

11. Shen Q, Shang N, Li P. In vitro and in vivo antioxidant activity of Bifidobacterium animalis 01 isolated from centenarians. Curr Microbiol. 2011;62(4):1097-103. https://doi.org/10.1007/ s00284-010-9827-7

PMid:21132298

12. Persichetti E, Chiasserini $D$, Parnetti L, Eusebi $P$, Paciotti $S$, Carlo CD, et al. Factors influencing the measurement of Iysosomal enzymes activity in human cerebrospinal fluid. PLoS One. 2014;9(7):e101453. https://doi.org/10.1371/journal. pone.0101453 PMid:24983953

13. Wang AN, Yi XW, Yu HF, Dong B, Qiao SY. Free radical scavenging activity of Lactobacillus fermentum in vitro and its antioxidative effect on growing-finishing pigs. J Appl Microbiol. 2009;107(4):1140-8. https://doi. org/10.1111/j.1365-2672.2009.04294.x PMid: 19486423

14. Nardone A, Ronchi B, Lacetera N, Ranieri MS, Bernabucci U Effects of climate changes on animal production and sustainability of livestock system. Livest Sci. 2010;130(1):57-69. https://doi.org/10.1016/j.livsci.2010.02.011 